\title{
Evaluation of the mechanism of modulation of Securidaca longipendunculata towards regulation of arterial blood pressure
}

\author{
Salami $\mathrm{HA}^{1 *}$, Ayo JO${ }^{2}$, Olorunshola $\mathrm{KV}^{3}$ and Adelaiye $\mathrm{AB}^{3}$ \\ ${ }^{1}$ Department of Human Physiology, University of Maiduguri, Nigeria \\ ${ }^{2}$ Department of Veterinary Physiology and Pharmacology, Ahmadu Bello University, Zaria, Nigeria \\ ${ }^{3}$ Department of Human Physiology, University of Abuja, Nigeria
}

\begin{abstract}
This study examined the significance of EESL on vascular smooth muscle regulation towards controlling high blood pressure as claimed by herbalist. Aortic rings of normotensive 10 wistar albino rats were used during the experiments. The EESL exert dual effect on 5 -HT induced vasoconstriction; at lower dose (3.5mg/20ml in Kreb's isolate solution), it potentiates vasodilation while at high doses $(5 \mathrm{mg}-20 \mathrm{mg} / 20 \mathrm{ml})$ it potentiates vasoconstriction, and these two effects were abolished after endothelium removal. Potentiation of $5-\mathrm{HT}$ induced vasoconstriction by EESL was however significantly $(\mathrm{p}<0.05$ ) greater when normal calcium was present in Kreb's isolate solution compared to low calcium in solution. The activity of EESL was found to be calcium dependent NO synthase because presence of NO synthase inhibitor in Kreb's solution caused spontaneous vasorelaxation. These results indicate that EESL act on 5-HT receptor subtype and based on this finding the activity of EESL is through endothelial cell. Furthermore, the calcium- dependent and NO synthase may probably be the mechanism by which EESL induce both vasoconstriction and vasodilation effect.
\end{abstract}

\section{Introduction}

Persistent high blood pressure (hypertension) ensure when physiological system regulating blood pressure such as vascular endothelium, L-arginine NO pathways etc. are altered [1]. In deed studies in human revealed the association of hypertension with No generation depletion [2]. Increased arterial reactivity due to dysregulation in endothelial nitric oxide synthase (eNOS) and prooxidant enzymes enhanced basal and activated calcium level due to overactive trans-membrane calcium permeability, such accumulation therefore release endothelial contraction factors (EDCF) which is seen in spontaneous hypertensive rats [3]. Also, the changed in abundance or sensibility of important component of the EDCF cascade is been seen as contribution to the level of endothelium dependent contraction since expression of prostacyclin synthase [4], cox-1 [5] and endothelial sensitivity to TP reception located on the smooth muscle cell were all altered in an aorta of spontaneous hypertensive rats. Therefore [5], evaluation of medication uses in addressing or antagonizing persistent high blood pressure will go a long way to achieved good prognosis. In orthodox practice, combine medication, such as diuretic, angiotensin enzyme convertase inhibitor, calcium-channel blocker and B-blocker are used as an initial line of action to address hypertension [6]. Each of these drugs exert its effect differently to achieve gold objective. However traditional use of herbal preparation though the mechanism of some of these plants have been authenticated [7] other herbs are still awaiting the evidence for their mechanism of action.

In our earlier report on plant Securidaca longipendunculata on isolated heart [8] and in-vivo effect of this plant on regulation of cardiovascular system [9], we demonstrated that the plant extract, its regulation on blood pressure through calcium channel, but to what extent this regulation will involve vascular endothelium has not been properly documented. It is known that calcium ion dependent NO synthase in the endothelia cell regulate normal blood pressure by releasing NO which in turn modulate vascular smooth muscle tone. This experiment is therefore designed to evaluate effect of extract of SL on calcium signaling toward endothelial releasing nitric oxide.

\section{Methodology}

Ten normotensive Wistar rats (200-250gm) were anesthetized briefly with chloroform (100\%) followed by exsanguination. The thoracic aorta was removed and dissected free from surrounding connective tissue and cut into ring segment of about $2-3 \mathrm{~mm}$ long. The endothelium was removed from some of the rings by gentle rubbing of the internal surface with a pipe cleaner, while others were left intact. Each ring was mounted for isometric tension recording on stainless steel hook in an organ bath filled with $20 \mathrm{ml}$ of Kreb's Henseilet solution $(\mathrm{mM})\left(\mathrm{NaCl}, 119.0, \mathrm{KCL}, 4.5 ; \mathrm{CaCl}_{2}, 2.5 ; \mathrm{MgSO}_{4}, 1.2 ; \mathrm{KHPO}_{4}, 1.2\right.$; $\mathrm{NaHCO}_{3}, 24.8$; and glucose 10.3) and gassed continuously with $95 \%$ $\mathrm{O} 2,5 \% \mathrm{CO}_{2}$ then maintained at $\mathrm{pH} 7.4$ and at $37^{\circ} \mathrm{C}$. The rings with or without functional endothelium were given a stretched tension of 2000 $\mathrm{mg}$ force. Isometric tension changes were monitored using an isometric

${ }^{\star}$ Correspondence to: Salami HA, Department of Human Physiology, University of Maiduguri, Nigeria, E-mail: adegokee2009@yahoo.com

Key words: Securidaca longipendunculata, endothelium, calcium channel blocker, persistent arterial blood pressure, nitric oxide synthase

Received: September 17, 2018; Accepted: September 28, 2018; Published: October 02,2018 
traducer (Grass Ft 03), which was in turn connected to grass model 7D polygraph for recording isometric contraction. The ring was allowed to equilibrate for $30 \mathrm{~min}$, during which they were stimulated twice with $5 \mathrm{HT}\left(10^{-5}\right.$ mole $)$ at $15 \mathrm{~min}$ interval and also the Kreb's buffer was changed. After 5HT-induced contraction reached maxima contraction, the extract was added in a step-wise manner into the organ bath, and the effects of the extract were obtained.

\section{Influence of the extract on aortic ring with intact endothelium and denuded endothelium}

The rings were pre-contracted with $5 \mathrm{HT}\left(10^{-5} \mathrm{~mole}\right)$ and when the contraction attained a steady state, increasing concentrations of extract were added cumulatively. On the other hand, the endothelium was removed from some of aortic rings to assess the influence of extract on the deluded endothelium.

\section{Effect of different $\mathrm{Ca}^{2+}$ concentration in Kreb's solution on extract-induced responses}

Two concentrations of calcium ion $(1.0 \mathrm{mM}$ and $0.4 \mathrm{mM})$ in Kreb's solution were used. The rings were pre-contracted with $5 \mathrm{HT}(10$ ${ }^{5}$ mole) until the contraction attained a stead state, then increasing concentrations of the extract were added cumulatively and the response was recorded.

\section{Effect of NO blockade on extract responses}

Nitric oxide synthase inhibitor NO nitro-arginine (L-NAME) was added into Kreb's solution in organ bath. The rings were incubated for 30 minutes before addition of cumulative doses of the extract, and the contractile responses of the muscle obtained was then recorded.

\section{Results}

\section{Effect of extract of Securidaca longipedunculata on 5HT - induced vasoconstriction of intact aortic rings}

The Kreb's solution containing normal calcium $(1.6 \mathrm{mMol})$ was used. The aortic rings first pre-contracted with $5 \mathrm{HT}\left(10^{-5} \mathrm{~mole}\right)$ from zero level to $1436 \pm 13.8 \mathrm{mg}$ force, serial doses of extract of EESL were then added cumulatively. The extract showed no change in tension developed at low doses $(0.1 \mathrm{mg}, 0.2 \mathrm{mg}$ and $1 \mathrm{mg})$. Further addition of $2 \mathrm{mg}$ of EESL to the solution, inhibited significantly $(\mathrm{P}<0.001) 5 \mathrm{HT}(10$ ${ }^{5}$ mole) -induced contraction from $1436 \pm 13.8$ to $660 \pm 10.7 \mathrm{mg}$ force (the cumulated dose was $3.3 \mathrm{mg} / 20 \mathrm{ml}$ of solution). Further addition of EESL (5mg, 10mg, and 20mg 40mg) cumulatively enhanced 5HT $\left(10^{-5}\right.$ mole)-induced contraction of the aortic ring. The maximum tension developed were $1745 \pm 8.00,1930 \pm 3.00$ and $1890 \pm 6.78 \mathrm{mg}$ $1890 \pm 6.78 \mathrm{mg}$ force, respectively, (Figure 1a). It appears that EESL has dual effect on 5 HT $\left(10^{-5}\right.$ mole)-induced contraction; at low doses it inhibits, while at high doses it potentiates $5 \mathrm{HT}\left(10^{-5}\right.$ mole $)$-induced contraction (Figure.1a).

\section{Low Ca2+ concentration in Kreb's solution and the contractile responses to the extract of Securidaca longipendunculata}

The Kreb's solution containing $0.4 \mathrm{mM}$ of $\mathrm{Ca}^{2+}$ ion stead of $1.6 \mathrm{mM}$ was used to investigate whether calcium-ion play a role in EESL-induced contraction. At low $\mathrm{Ca}^{2+}(0.4 \mathrm{mM})$ in the Kreb's, the mean contractile responses of aortic rings to $5 \mathrm{HT}\left(10^{-5} \mathrm{~mole}\right)$-induced was $471 \pm 77.4 \mathrm{mg}$ force instead of $1436 \pm 13.8 \mathrm{mg}$ force obtained with normal calcium concentration in Kreb's solution. After contraction attained a stead state, the extract was then added cumulatively and contractions values were $471 \pm 77.4 \mathrm{mg}, 471 \pm 77.4 \mathrm{mg}, 471 \pm 77.4,75 \pm 00.00,910 \pm 47.4$,
99043.0 and $1000 \pm 00.00 \mathrm{mg} 1000 \pm 00.0$ tension at doses of $0.1 \mathrm{mg}$, $0.2 \mathrm{mg}, 1 \mathrm{mg}, 2 \mathrm{mg}, 5 \mathrm{mg} 10 \mathrm{mg}$, $20 \mathrm{mg}$ and $40 \mathrm{mg}$ of extract respectively added cumulatively. These values were significantly $(\mathrm{P}<0.001)$ less than the tension value obtained with normal calcium ion $(1.6 \mathrm{mM})$ in Kreb's (1226 $\pm 13.46 \mathrm{mg}, 1426 \pm 13.46 \mathrm{mg}, 1426 \pm 13.4 \mathrm{mg}, 660 \pm 10.77 \mathrm{mg}, 1745$ $\pm 80.00 \mathrm{mg}, 1930 \pm 30.00 \mathrm{mg}$ and $1890 \pm 30.00 \mathrm{mg}$ tension respectively), (Figure 1b). EESL exerted dose-dependent constriction at high doses while at low concentration $(3.5 \mathrm{mg})$ the extract inhibited $5 \mathrm{HT}\left(10^{-5}\right.$ mole)-induced contraction. It was also observed that at $3.5 \mathrm{mg}$ EESL in solution, the inhibition by the extract to 5HT (10-5 mole)-induced contraction was higher $(\mathrm{P}<0.05)$ in low $\mathrm{Ca}^{2+}(75 \pm 0.00 \mathrm{mg}$ tension $)$ when compared with normal $\mathrm{Ca}^{2+}(1.6 \mathrm{mM})$ in Kreb's solution $(666 \pm$ $10.77 \mathrm{mg}$ tension), Figure $1 \mathrm{a}$ and $1 \mathrm{~b}$. However, concentrations lower than $3.5 \mathrm{mg}$ did not also showed any changes to $5 \mathrm{HT}\left(10^{-5}\right.$ mole $)$ induced contraction of aortic rings in both two solutions.

\section{Contraction responses to the EESL extract in the absence of endothelium}

The contractile effect of EESL was investigated on aortic rings without endothelium. The effectiveness of the procedure for endothelium removal was confirmed by failure of acetylcholine relaxes $\mathrm{KCl}$ pre-contracted rings, and a normal response to acetylcholine has been used as an index of normal endothelial function [10]. Some rubbed aortic rings lack spontaneous activity with the EESL, while few rings demonstrate a slight contraction. This suggests the importance of normal endothelial lining for normal action of EESL.

\section{Effect of extract on L-NAME}

The rings were contracted twice with $5 \mathrm{HT}\left(10^{-5} \mathrm{~mole}\right)$, in the medium with normal calcium in Kreb's solution. The rings incubation with L-NAME in Kreb's solution showed no contractile response in some rings while those that showed little response were not stable as tissue relaxed spontaneously.

\section{Discussion}

The findings of the present study showed that the EESL relaxed 5HT $\left(10^{-5} \mathrm{~mole}\right)$ pre-contracted rat aortic ring at low doses $(0.1 \mathrm{mg}, 0.2 \mathrm{mg}$, $1 \mathrm{mg}$, and $2 \mathrm{mg}$ ), while at high $(5 \mathrm{mg}, 10 \mathrm{mg}, 20 \mathrm{mg}$, $40 \mathrm{mg})$ doses EESL enhanced $5 \mathrm{HT}\left(10^{-5}\right.$ mole $)$ induced contractile response of aortic rings. That the potentiation of EESL on $5 \mathrm{HT}\left(10^{-5}\right.$ mole $)$ induced constriction suggested that the EESL may be acting on serotonergic receptor. Nilsson et al., and Chester et al., demonstrated the existence of multiple 5 HT receptor sub-type expression in human blood vessel, of which

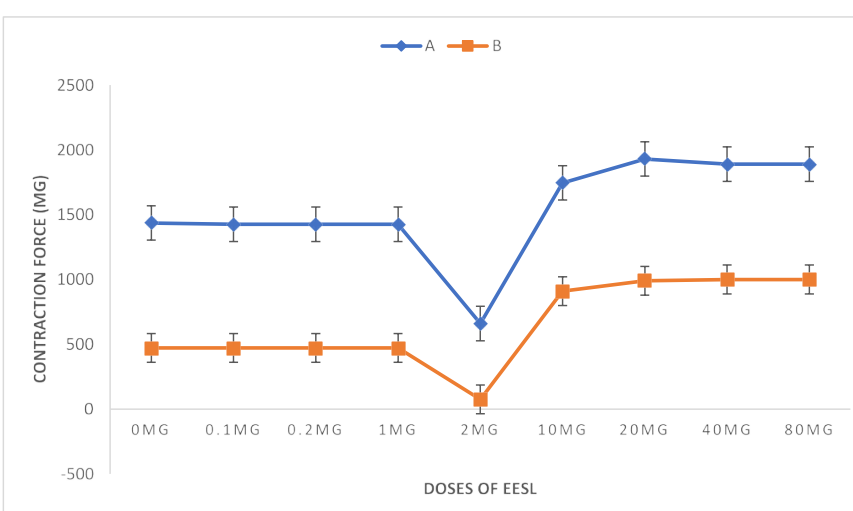

Figure 1. Comparative of cumulative response of the 5HT $\left(10^{-5}\right)$ pre-contracted aortic ring to extract of Securidaca longipendulata to normal calcium ion $(\mathrm{A}=1.6 \mathrm{mMol})$ and low calcium ion $(\mathrm{B}=0.4 \mathrm{mMol})$ in Kreb's solution 
two are known to be involved in the contraction of human vascular smooth muscle; namely $5 \mathrm{HT}_{1}$ and $5 \mathrm{HT}_{2}$ receptors [11,12]. They also showed that $5 \mathrm{HT}_{1 \mathrm{~b}}$ or $5 \mathrm{HT}_{1 \mathrm{a}}$ subtype mediated the contractile effect of $5 \mathrm{HT}$ in human vascular smooth muscle. A similar report from studies on experimental animals showed the presence of $5 \mathrm{HT}_{2 \mathrm{a}}$ in peripheral vascular smooth muscle and it mediated exogenous serotonin [13]. Although this study did not attempt to fully characterize the receptor type upon which the extract acted, earlier report has demonstrated that exogenous serotonin mediates its effect through $5 \mathrm{HT}_{2 \mathrm{a}}$ receptor; thus, suggesting that the potentiating effect of EESL may be through the same $5 \mathrm{HT}_{2 \mathrm{a}}$ receptor of exogenous serotonin.

This is a significant finding because potentiation or activation of serotonergic receptor is a mechanism underling the treatment of depression and hallucination [14]. Indeed, the root extract is mostly used in traditional medicine to treat psychiatric problems and is, therefore, called "Maganin Mayu" (i.e. Witch's medicine). In South Africa, the Chopi and Kung tribes used the roots as medicine for people possessed by evil spirit and in healing section, [15]. This area needs further investigation.

In view of the transient relaxation induced by low dose of EESL, the relaxation, therefore may be attributed to either another 5HT receptor subtype other than $5 \mathrm{HT}_{2 \mathrm{a}}$ receptor or another mechanism, probably endothelium-derived relaxation factors. However other evidences have shown that the interaction between 5HT and sumatriptan observed in radial artery resulted in co-stimulation that released endotheliumderived vasodilation factor which suppressed the contraction induced by either of these agents [16].

It is likely that at low doses of EESL, both $5 \mathrm{HT}\left(10^{-5}\right.$ mole $)$ and extract inhibited the contraction induced by either of them because convincing report of Adrian et al., indicated that $5 \mathrm{HT}_{2 \mathrm{~B}}$ and $5 \mathrm{HT}_{1 \mathrm{c}}$ subtype receptors mediate endothelium-dependent relaxation of the rat and cat jugular vein, and also possibly pig pulmonary artery, via nitric oxide release [16]. Whether or not EESL also possesses this action requires further investigation.

The observed potentiation effect of EESL on 5HT induced contraction at high doses of extract may also be attributed to calcium channel mechanism. The previous study on isolated rabbit heart showed that the vasoconstrictive effect of EESL on coronary artery was antagonized by nifedipine, a calcium ion channel blocker [8]. This fact suggests that the concentration-dependent factor contributed to either opening or closing of calcium channels. The finding of Stanislav et al., supports the view that high calcium concentration causes rapid opening, while low concentration causes slow activation of the calcium channel [17].

Further investigation into whether calcium does play a role in both relaxation and contraction response induced by EESL was carried out using varying concentrations of external calcium ion in the two physiological salt solution ( 1.6 to $0.4 \mathrm{mM}$ ). The result showed that at low external $\mathrm{Ca}^{2+}$ concentration in the solution, the enhanced contractile effect of EESL on 5HT $\left(10^{-5}\right.$ mole) induced contraction decreased. There was comparable less contraction of the ring in 0.4 to $1.6 \mathrm{mM}$ in Kreb's solution. This finding supports the previous report that endothelium-dependent contractions are reduced when the external $\mathrm{Ca}^{2+}$ concentration is lowered and can be evoked by calcium ionophore A23187 [18,19].

It is a conceivable fact that the contractile agonist utilized calcium from two main sources in smooth muscle: extracellular and intracellular [20]. It is suggestive that EESL utilized the extracellular calcium.
This view is supported by the finding in the present study that low contractile responses of the rings is observed in the media contained less calcium. The study, therefore, suggests that the contraction evoked by the extract depends on calcium ion. The role of calcium channel was also studied by incubation of the rings in Kreb's solution, containing $0.2 \mathrm{mg}$ nifedipine, where absolute relaxation was recorded. The findings gave additional support to our earlier view that the marked increase in coronary flow observed after co-administration of EESL and nifedipine was due to calcium channel blockade, and that the extract modulated these channels [8].

The importance of endothelium modulation of vascular smooth muscle through endothelium-derived contracting factor and endothelium-derived relaxing factor was observed in many studies [21,22]. Endothelial cell can induce relaxation of the underlying vascular smooth muscle by generating NO, prostacycline and through a non-characteristic endothelium-derived hyperpolarization factor [23]. On the other hand, endothelium can also contract the underlying vascular smooth muscle by generating the vasoconstrictor protanoids endothelium-dependent contracting factor [22].

The NO is formed in endothelial cells from the guanidine-nitrogen terminal of L-arginine, by the constitutive NO-synthase III, (eNOS). The activation of NO synthase III depends on the intercellular concentration of calcium ions in the endothelial cells, as it is $\mathrm{Ca}^{2+}$-calmodulindependent. NO diffuses to the vascular smooth muscle cells and relaxes them mainly by stimulating production of cyclic $3^{1} 5^{1}$ - guanosine monophosphate (cGMP), leading to inhibition of the contractile process [24]. These may be seen as a mechanism of relaxation responses to $5 \mathrm{HT}\left(10^{-5}\right.$ mole)-induced contraction caused by EESL at low doses. The role of NO involvement in mechanism of dilation in this work was carried out because several studies have shown that nitric oxide exerts acute and chronic inhibitory effects on the production of endotheliumdependent contraction [10], and, thus, justifies the pre-treatment of aortic rings with the NO synthase blocker L-NAME to optimize the production of endothelium-cyclooxygenase-dependent contractions $[3,25]$. No contraction was obtained in the presence of L-NAME at high doses. This may be due to the inability of EESL to accumulate and release enough calcium in the endothelium cell to trigger initial step of the endothelium-derived contracting factor cascade. The fact that EESL fails to produce endothelium-dependent contraction in the presence of L-NAME is in line with the previous data on effect of acetylcholine on aortic ring [26]. The Studies shown that when L-NAME was absent, acetylcholine accumulates calcium ions triggers the release of oxidative stress in both WKY and SHR being significantly more prominent in the latter, the process was however prevented when either L-NAME or antioxidants were present. The action of EESL could resemble acetylcholine effect on aortic rings pre-treated with L-NAME [3], as no contraction was also obtained because the presence of L-NAME affects calcium ion accumulation by acetylcholine that triggered induction of oxidative stress. The endothelium-dependent contraction is suggested to be responsible for contraction observed at high doses of the extract. This conception is supported by the following observations: (1) High calcium concentration in Kreb's solution causes more contractile response. (2) No contraction was obtained when endothelium was removed.

This data supports the concept that an increase in intracellular calcium ion is necessary for the production of endothelium-dependent contractions $[18,25]$. Other studies also indicated that high calcium levels are required to initiate the release of endothelium-derived contracting factor, and substance like A23187, which increases calcium 
ion entry causes contraction in both spontaneous hypertensive and normotensive rats [3].

The role of endothelium in mediating EESL effect was further carried out with de-endothelization. Some of rings showed little contraction, while others did not give any response to EESL-induced contraction. One explanation is that endothelium constitutes a diffusion barrier and its removal may disrupt calcium ion transport mechanism in endothelial cells. This implies that EESL might have induced contraction by accumulating endothelial calcium ion through calcium ion channel. We therefore concluded, that the EESL possessed dual effect on blood vessel; low dose relaxes aortic rings while high dose potentiates 5-hydroxytryptamin-induce aortic contraction therefore justified herbalist use of the plant for control of hypertension and psychiatric disorders. Based on our findings the EESL act through endothelium, calcium ion channel and 5-HT receptor, It is also obvious that calcium ion plays two roles in EESL modulation of vascular smooth muscle; either dilating through receptor-mediated increases in intracellular calcium ion, which result in NO formation, or constriction via excess accumulation of calcium ion.

\section{References}

1. Rees DD, Palmer RM, Moncada S (1989) Role of endothelium-derived nitric oxide in the regulation of blood pressure. Proc Natl Acad Sci U S A 86: 3375-3378. [Crossref]

2. Panza JA, Quyyumi AA, Brush JE, Epstein SE (1990) Abnormal endothelium dependent vascular relaxation in patient with essential hypertension. $N$ Engl J Med 232: 22-27. [Crossref]

3. Tang EHC, Leung FP, Huang Y, Feletou M, So KF, et al. (2007) Calcium and reactive oxygen species increase in endothelium cells in response to release of endotheliumderived contracting factor. Br J Pharmacol 151: 15-23. [Crossref]

4. Numaguchi Y, Harada M, Osanal H, Hayashi K, Toki Y et al (1999) Altered gene expression of prostacyclin synthesis and prostacyclin receptor in the thoracic aorta of spontaneously hypertensive rats. Cardiovasc Res 41: 682-688.

5. Ge T, Hughes H, Junquero DC, Vanhoutte PM, Boulanger CM (1995) Endothelium dependent contraction are associated with both augmented expression of prostaglandin $\mathrm{H}$ Synthase and hypersensitivity to $\mathrm{H} 2$ in the spontaneous hypertensive rat aorta. Circ Res 76: 1003-1010. [Crossref]

6. Caro JJ, Jeanne CM, Speckman LS, Salas M, Raggio G (1999). Effect of initial drug choice on persistence with antihypertensive therapy: the importance of actual practice data. Can Med Assoc J 160: 41-46.

7. Al Disi SS, Anwar MA, Eid HA (2015) Antihypertensive herbs and their mechanisms of action. Part 1. Front Pharmacol 6:323 [Crossref]

8. Salami HA, Ayo JO, Adelaiye AB, Olorunshola KV (2016) Effect of crude extract of Securidaca longipedunculata on isolated rabbit heart. Eur J Biomed Pharm Sci 3:103108.

9. Salami HA, Adelaiye AB, Tukur MA, Olorunsola KV, Ayo JO (2018) In vivo Modulatory Responses of Cardiovascular System to Ethanolic Extract of Securidaca Longipendunculata in Albino Rats. Surg Case Rep Rev 2: 1-4.
10. Yang D, Glaulis P, Zhang JN, Vanhoutt PM, Peletov M (2004) Endothelium dependent contraction to acetylcholine, ATP and calcium A23187 in aortal from spontaneously hypertensive and normotensive rats. Fundam Clin Pharmacol 18: 321-326. [Crossref]

11. Nilsson T, Longmere I, Pantery E, Bard J, Branchel T, et al. (1991) Characterization of 5-HT receptor in human coronary arteries by molecular and pharmacological techniques. Eur J Pharmacol 372: 49-56. [Crossref]

12. Chester AH, Martin GB, Bodelssan M, Arneklo NB, Tadjkarimi S, et al. (1990) Hydroxytryptamine receptor profile in health and disease human epicardiac coronary arteries. Cardiovasc Res 25: 932-937.

13. Francis GS (2001) Pathophysiology of chronic heart failure. Am J Med 110: 37S-46S [Crossref]

14. Marek GJ, Carpenter LL, Mcdougle CJ, Price LH (2003) Synergistic action of 5HT2A antagonists and selective serotonin reuptake inhibitors in neuropsychiatric disorders. Neuropsychopharmacology 28: 402-412. [Crossref]

15. Winkleman M, Dobkin de Rios M (1989) Psychoactive properties of Kung bushman medicinal plants. J Psychoactive Drugs 21:51-59. [Crossref]

16. Adrian HC, Mohamed A, Camilla AS, Magdi HY (2000) Interaction between thromboxane A2 and 5-hydroxytryptamine in the radial artery compared to the internal thoracic artery. Gen Pharmacol 35: 89-93.

17. Stanislav BR, Marksteiner FG, Maartina JS, Steffen H (2000) Molecular mechanism of calcium channel block by isradipine. Role of a drug-induced inactivated channel conformation. J Biol Chem 275: 22114-22120. [Crossref]

18. Gluais P, Paysant J, Badier-Commander C, Verbeuren T, Vanhoutte PM, et al. (2006) In SHR aorta, calcium ionophore A-23187 releases prostacyclin and thromboxane A2 as endothelium-derived contracting factors. Am J Physiol Heart Circ Physiol 291: H2255-H2564. [Crossref]

19. Shi Y, Feletou M, Ku DD, Man RY, Vanhoutte PM (2008) The calcium ionophore A23187 induces endothelium-dependent contractions in femoral arteries from rats with streptozotocin-induced diabetes. Br J Pharmacol 150: 624-632. [Crossref]

20. Bolton TB (1979) Mechanism of action of transmitter and other substances on smooth muscle. Physiol Rev 59: 606-718. [Crossref]

21. Vanhoutte PM, Feleton M, Taddei S (2005) Endothelium-dependent constrictions in hypertension. Br J Pharmacol 144: 449-458. [Crossref]

22. Vanhoutte PM, Tang EH (2008) Endothelium-dependent contraction. When a good guy turns bad? J Physiol 586: 5295-5304. [Crossref]

23. Büssemaker E, Popp R, Fisslthaler B, Larson CM, Fleming I, (2003)Aged spontaneously hypertensive rats exhibit a selective loss of endothelium-derived hyperpolarization factor mediated relaxation in the renal artery. Hypertension 42: 562-568. [Crossref]

24. Vanhoutte PM (2003) Endothelial control of Vasomotor function from health to coronary disease. Circ J 67: 572-575. [Crossref]

25. Yang D, Glualis P, Zhang JN, Vanhoutte PM, Peletov M (2004) Nitric oxide and inactivation of the endothelium-dependent contracting traitor released by acetylcholine in spontaneously hypertensive rat. J cardiovasc Pharmacol 43: 820-825.

26. Zhu J, Yu M, Friesema J, Huang T, Roman RJ (2004) Salt-induced ANG II suppression impairs the response of cerebral artery smooth muscle cells to prostacyclin. Am J Physiol Heart Circ Physiol 288: H908-H913. [Crossref]

Copyright: (C2018 Salami HA. This is an open-access article distributed under the terms of the Creative Commons Attribution License, which permits unrestricted use, distribution, and reproduction in any medium, provided the original author and source are credited. 